J. Akademika Kim. 5(1): 50-54, February 2016

ISSN 2302-6030 (p), 2477-5185 (e)

\title{
PENGARUH WAKTU FERMENTASI TERHADAP KADAR PROTEIN DARI TEMPE BIJI BUAH LAMTORO GUNG (Leucaena leucocephala)
}

\section{Effect of Fermentation Time to the Protein Levels of Fermented Lamtoro Gung (Leucaena leucocephala) Fruit Seed}

\author{
*Muthmainna, Sri Mulyani Sabang, dan Supriadi \\ Pendidikan Kimia/FKIP - Universitas Tadulako, Palu - Indonesia 94118 \\ Received 20 December 2015, Revised 24 January 2016, Accepted 21 February 2016
}

\begin{abstract}
Lamtoro gung (Leucaena leucocephala) is one of the food materials containing high enough protein which allow to be used as raw material for producing tempeh through fermentation. This study aimed to determine the effect of fermentation time to the protein levels of lamtoro gung seeds tempeh with variation fermentation times of 24 hours, 36 hours, 48 hours, 60 hours and 72 hours. Steps in this study were sample preparation, producing lamtoro gung seeds tempeh, and protein levels analysis. The protein level was determined by Kjeldahl method. The results showed that there was an effect of fermentation time to the protein levels. The longer the fermentation time took effect to the lower the levels of protein produced. The highest protein level was obtained at 24 hours of fermentation time that was equal to $7.943 \%$, while the protein level on fermentation time of 36 hours was equal to $7.725 \%$, 48 hours fermentation time was equal to $7195 \%$, 60 hours fermentation time was equal to $7197 \%$, and 72 hours fermentation time was equal to $5733 \%$.
\end{abstract}

Keywords: Lamtoro gung (Leucaena leucocephala) seed, fermentation, protein

\section{Pendahuluan}

Masalah kecukupan gizi saat ini merupakan masalah yang perlu mendapatkan perhatian yang cukup serius terutama bagi negara yang sedang berkembang. Hal ini disebabkan karena kurang seimbangnya jumlah penduduk dengan jumlah produksi pangan sumber gizi. Jumlah produksi pangan sumber gizi yang kurang mencukupi disebabkan belum skrening terhadap bahan makanan sebagai sumber gizi, serta tingkat tekhnologi negara berkembang khususnya dalam produksi dan pengolahan pangan masih belum memadai (Widodo, 2012).

Pangan merupakan kebutuhan yang paling esensial bagi manusia untuk mempertahankan hidup dan kehidupannya. Pangan sebagai sumber zat gizi (karbohidrat, lemak, protein, vitamin, mineral dan air) menjadi landasan utama manusia untuk mencapai kesehatan dan kesejahteraan sepanjang siklus kehidupan. Melalui penganekaragaman pangan, dapat dipenuhi kebutuhan zat gizi yang dibutuhkan

\section{${ }^{*}$ Correspondence:}

Muthmainna

Program Studi Pendidikan Kimia, Fakultas Keguruan dan

IImu Pendidikan, Universitas Tadulako

email: muthmainna07511@gmail.com

Published by Universitas Tadulako 2016 oleh manusia. Usaha penganekaragaman pangan dapat dilakukan dengan mencari bahan pangan baru atau bahan dari pangan yang sudah ada dan dikembangkan menjadi bahan pangan yang beraneka ragam dengan harga yang relatif terjangkau oleh masyarakat (Setyaningsih, dkk., 2009)

Tempe sebagai sumber protein yang baik dalam menu makanan Indonesia. Tempe pada umumnya terbuat dari kedelai rebus yang difermentasi oleh jamur rhizopus. Bahan pangan berprotein nabati yang banyak dipergunakan sebagai bahan dasar fermentasi pangan adalah kedelai atau jenis kacang-kacangan lain, seperti kacang tanah, kara benguk, dan kacang gude. Di antara bahan-bahan tersebut, kedelai paling sering digunakan sebagai bahan dasar makanan fermentasi di beberapa Negara karena kadar proteinnya yang tinggi (Rosida, dkk., 2009). Protein kedelai memiliki peran dalam mengurangi risiko kanker tertentu, terutama kanker payudara, usus besar dan kanker prostat (Babu, dkk., 2009).

Indonesia merupakan negara produsen tempe terbesar di dunia dan menjadi pasar kedelai terbesar di Asia. Sebanyak 50\% dari konsumsi kedelai di Indonesia dilakukan dalam 
bentuk tempe, $40 \%$ tahu dan $10 \%$ dalam bentuk lain (seperti touce, kecap, dll) (Hayati, 2009).

Kenaikan harga kedelai yang berimbas pada kenaikan harga tempe mengakibatkan penurunan tempe sebagai salah satu sumber protein oleh masyarakat. Kelangkaan kedelai yang dialami Indonesia saat ini tentu tidak berarti telah terjadi krisis pangan, karena kedelai hanya salah satu dari sekian banyak komoditas pangan yang menjadi menu makanan kita sehari-hari. Tetapi, bagi keluarga yang mengandalkan tahu - tempe sebagai sumber protein, sekarang harus repot mencari sumber protein yang lain (Hayati, 2009).

Salah satu bahan pengganti kedelai adalah biji lamtoro gung. Biji lamtoro gung mempunyai kandungan protein yang cukup tinggi bila dibandingkan dengan golongan bijibijian yang lain, yaitu berkisar antara $30-40 \%$. Biji lamtoro gung juga mengandung beberapa zat penting lain, di antaranya kalori, hidrat arang, kalsium, fosfor, zat besi dan vitamin A, B1 dan C (Rosida, dkk., 2009).

Penanganan, penyimpanan dan pengawetan bahan pangan sering menyebabkan terjadinya perubahan nilai gizinya, yang sebagian besar tidak diinginkan. Zat gizi yang terkandung dalam bahan pangan akan rusak pada sebagian besar proses pengolahan karena sensitif terhadap $\mathrm{pH}$, oksigen, dan sinar matahari (Palupi, dkk., 2007). Tulisan ini mendeskripsikan penelitian tentang pengaruh waktu fermentasi terhadap kadar protein dari tempe biji buah lamtoro gung.

\section{Metode \\ Alat dan Bahan Penelitian}

Alat-alat yang digunakan dalam penelitian meliputi: spektrofotometer direct (RS232 Lovibond), Kjeldahl Term, Gelas kimia $50 \mathrm{~mL}$, Pemanas listrik, neraca digital, gelas ukur 10 $\mathrm{mL}$, batang pengaduk, spatula, botol semprot, pipet tetes, gegep, panci, kompor, saringan, wadah (Loyang), plastik pembungkus dan jarum.

Bahan-bahan yang digunakan meliputi: biji buah lamtoro gung kering, ragi tempe, $\mathrm{H}_{2} \mathrm{SO}_{4}$ Pekat (Merck KGaA), aquades dan tablet Kjeldahl.

\section{Prosedur Penelitian}

\section{Pembuatan Tempe Lamtoro Gung}

Pembuatan tempe lamtoro gung diawali dengan pengupasan kulit lamtoro dan pemilihan biji untuk mendapatkan biji lamtoro yang berkualitas baik. Selanjutnya biji lamtoro tersebut direbus selama 30 menit lalu ditiriskan. Kemudian biji lamtoro direndam selama 24 jam dan airnya diganti sebanyak 3 kali sehari. Setelah itu, kulit biji buah lamoro dihilangkan dengan cara diremas-remas menggunakan tangan untuk mempermudah jamur menembus keping biji lamroro pada saat proses fermentasi. Kemudian direbus kembali selama 30 menit dan ditiriskan sampai benar - benar kering. Lalu ditaburi ragi tempe dengan komposisi ragi $0.5 \%$ dari berat biji lamtoro, kemudian diaduk sampai rata. Selanjutnya biji lamtoro yang sudah tercampur rata dengan ragi dibungkus dengan menggunakan plastik. Plastik tersebut dilubangi dengan menggunakan jarum yang berukuran besar untuk setiap sisi atas dan sisi bawah. Langkah terakhir yaitu difermentasikan dengan variasi waktu 0 jam (tanpa fermentasi), 24 jam, 36 jam, 48 jam, 60 jam dan 72 jam.

\section{Analisis Kadar Protein}

Analisis kadar protein pada tempe lamtoro gung dilakukan dengan menggunakan metode Kjeldahl. Langkah pertama yaitu sebanyak 0,5 g sampel ditimbang lalu dimasukkan ke dalam labu Kjeldahl, ditambahkan $10 \mathrm{~mL}$ H2SO4 pekat dan 1 butir tablet Kjeldahl. Kemudian didestruksi menggunakan alat Kjeldahl term pada suhu \pm 4000 C sampai semua bahan dalam labu Kjeldahl larut dan cairan menjadi bening kehijauan. Selanjutnya setelah proses destruksi selesai, dibiarkan beberapa saat sampai dingin. Sebanyak $2 \mathrm{~mL}$ larutan yang telah didestruksi diencerkan sampai $10 \mathrm{~mL}$ kemudian dianalisis menggunakan spektrofotometer direct.

\section{Analisis data}

Berdasarkan hasil pengukuran yang diperoleh menggunakan alat spektrofotometer direct, maka data yang diperoleh dapat dihitung menggunakan persamaan (Muctadi, 2010): $\%$ Kadar Protein $=\% \mathrm{~N}$ x 6,25, dimana 6,25 merupakan faktor koreksi.

\section{Hasil dan Pembahasan Hasil Penelitian}

Dari hasil penelitian yang telah dilakukan, secara umum dapat diketahui bahwa lama fermentasi memberi pengaruh terhadap kadar protein. Hal ini dapat dilihat pada Tabel 1. 
Tabel 1. Kadar Protein Tempe Biji Buah Lamtoro Gung

\begin{tabular}{cc}
\hline $\begin{array}{c}\text { Waktu fermentasi } \\
(\mathrm{jam})\end{array}$ & $\begin{array}{c}\text { Kadar protein } \\
\text { rata-rata }(\%)\end{array}$ \\
\hline 0 & 8.474 \\
24 & 7.943 \\
36 & 7.725 \\
48 & 7.195 \\
60 & 7.197 \\
72 & 5.733 \\
\hline
\end{tabular}

Lamtoro gung atau petai cina adalah sejenis perdu dari Famili Fabaceae yang sering digunakan dalam reboisasi atau pencegahan erosi. Buah lamtoro gung yang muda dapat dijadikan sebagai lalapan dan bahan makanan yang biasa disebut dengan botok. Kandungan gizi biji lamtoro gung relatif lengkap dan tidak jauh berbeda dengan kandungan gizi biji kedelai (Sayudi, dkk., 2015).

Pembuatan tempe lamtoro gung diawali dengan proses prafermentasi yaitu perebusan, pembuangan kulit biji, perendaman dan pengukusan, yang dilanjutkan dengan fermentasi menggunakan ragi yang dapat berupa rhizopus oligosporus atau dapat juga dengan laru yang merupakan campuran beberapa ragi. Proses pembuatan tempe ini menguntungkan karena dapat meningkatkan kecernaan protein, penyerapan zat besi dan menurunkan zat anti gizi (Listyawati, dkk., 2001).

Penentuan kadar protein pada tempe biji lamtoro gung dengan menggunakan metode Kjeldahl pada dasarnya dibagi menjadi 3 tahapan yaitu, proses destruksi, proses destilasi dan proses titrasi. Namun pada penelitian ini, hanya dilakukan sampai pada tahap destruksi, hal ini disebabkan karena penentuan kadar nitrogen totalnya dilakukan dengan menggunakan alat spektrofotometer direct (Hendrayati \& Askar, 2003).

Tahap destruksi, sampel dipanaskan dengan menambahkan $\mathrm{H}_{2} \mathrm{SO}_{4}$ dan 1 butir tablet Kjeldahl sehingga terjadi destruksi protein menjadi unsur - unsurnya. Asam sulfat pekat yang ditambahkan dalam jumlah yang berlebihan, akan dipergunakan untuk membentuk garam ammonium sulfat, gas belerang dioksida dan sebagian bereaksi dengan katalisator untuk mempercepat terjadinya oksidasi pada proses destruksi (Hendrayati \& Askar, 2003).

Kadar protein sebelum fermentasi yaitu sebesar $8.474 \%$. Dari Tabel 1 dapat dilihat bahwa setelah proses fermentasi terjadi penurunan kadar kadar protein. Kadar protein tertinggi diperoleh pada fermentasi 24 jam yaitu $7.943 \%$. Sedangkan kadar protein pada waktu fermentasi 36 jam yaitu sebesar $7.725 \%$, fermentasi 48 jam sebesar $7.195 \%$, fermentasi 60 jam sebesar $7.197 \%$ dan fermentasi 72 jam yaitu sebesar $5.733 \%$. Fermentasi selama 72 jam ini juga merupakan fermentasi dengan kadar protein terendah. Perubahan tersebut dapat dilihat pada Gambar 1

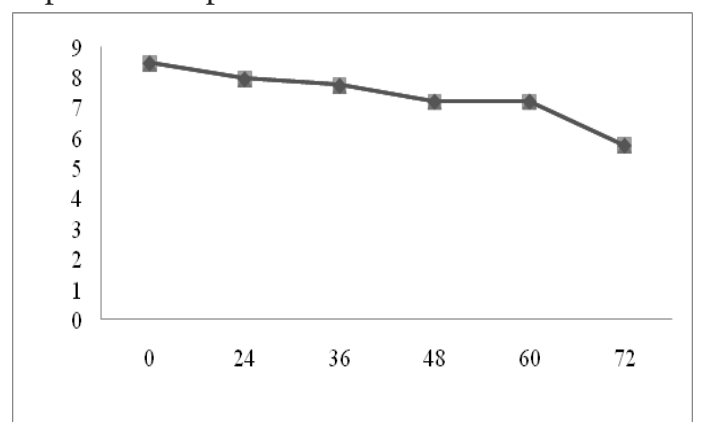

Gambar 1. Grafik Hubungan Antara Kadar Protein dengan Waktu Fermentasi.

Adanya pengurangan jumlah protein pada pembuatan tempe disebabkan oleh proses pengolahan tempe (food processing) seperti perendaman dan perebusan. Protein biji lamtoro gung dan biji kedelai memiliki bentuk protein globular. Protein globular memiliki sifat mudah larut dalam larutan garam dan asam encer, juga lebih muda berubah di bawah pengaruh suhu sehingga lebih mudah mengalami denaturasi (Sayudi, dkk., 2015).

Proses pemanasan juga akan membuat protein mengalami denaturasi. Denaturasi protein akan membuat protein rusak, sehingga dengan semakin banyak protein yang terdenaturasi menyebebakan terjadinya penurunan kadar protein (Sadli, 2014). Selain itu proses pemanasan juga akan meningkatkan daya cerna protein yang di hancurkan oleh enzim protease (Hassan, dkk., 2006).

Selama proses fermentasi banyak sekali jamur yang aktif, tetapi umumnya para peneliti menganggap bahwa rhizopus oligosporus merupakan jamur yang paling dominan. Jamur yang tumbuh pada tempe tersebut menghasilkan enzim-enzim pemecah senyawa-senyawa kompleks. rhizopus oligosporus menghasilkan enzim-enzim protease. Perombakan senyawa 
kompleks protein menjadi senyawa senyawa lebih sederhana yaitu asam amino adalah penting dalam fermentasi tempe, dan merupakan salah satu faktor utama penentu kualitas tempe, yaitu sebagai sumber protein nabati yang memiliki nilai cerna tinggi karena lebih mudah untuk diserap dan dimanfaatkan oleh tubuh secara langsung (Dwinaningsih, 2010). Selama proses fermentasi ada sejumlah protein yang digunakan oleh kapang rhizopus oligosporus sebagai sumber nitrogen untuk pertumbuhannya (Sayudi, dkk., 2015).

Jamur rhizopus oligosporus bersifat proteolitik dan ini penting dalam pemutusan protein menjadi unsur - unsurnya. Jamur ini akan mendegradasi protein selama fermentasi menjadi dipeptida dan seterusnya menjadi senyawa $\mathrm{NH}_{3}$ atau $\mathrm{NH}_{2}$ yang hilang melalui penguapan. Dengan semakin lama fermentasi berarti semakin lama kesempatan jamur mendegradasi protein, sehingga protein yang terdegradasipun semakin banyak, akibatnya protein tempe semakin menurun dengan semakin lama proses fermentasi (Deliani, 2008).

Waktu fermentasi juga memberikan pengaruh dalam kualitas produk suatu produk, produk fermentasi adalah produk yang dapat diterima baik secara kenampakan, aroma serta nutrisi yang dihasilkan (Darajat, dkk., 2014). Selama proses fermentasi tersebut terjadi peningkatan kelarutan zat-zat gizi terutama protein dan karbohidrat (gula terlarut). Dengan demikian fermentasi dapat membantu meningkatkan daya serap zat-zat gizi dalam tempe lamtoro gung tersebut (Komari, 1999).

Selama proses fermentasi berlangsung, tempe yang dihasilkan berbeda dengan tempe kedelai yang beredar dipasaran pada umumnya. Tempe yang diperoleh pada penelitian ini berwarna coklat dan kurang ditumbuhi oleh jamur atau miselium yang berwarna putih serta teksturnya kurang kompak. Hal ini disebabkan oleh kurangnya jumlah ragi/laru yang digunakan atau ragi yang digunakan sudah rusak (tidak aktif). Untuk mendapatkan tempe yang baik maka ragi yang digunakan ragi dalam keadaan aktif, artinya kapang tempe dapat tumbuh dengan baik. Ragi yang baru akan berpeluang mengahsilkan tempe yang baik yang akan berpengaruh terhadap pembentukan rasa, aroma dan flavor tempe yang dihasilkan (Silvia, 2009). Tempe yang baik adalah tempe yang kompak, seluruh tubuh diselimuti miselium kapang berwarna putih, tidak bernoda hitam akibat timbul spora, tidak berlendir, mudah diiris, tidak busuk dan tidak berbau amoniak
(Muslikhah, dkk., 2013).

Selain itu selama proses fermentasi berlangsung juga terdapat bau/aroma yang kurang baik pada waktu fermentasi 60 jam dan 72 jam. Serta pada fermentasi ini tekstur tempe sudah menjadi sangat lunak. Kemungkinan besar hal ini disebabkan oleh rusaknya jamur yang terdapat pada tempe. Bau busuk pada tempe disebabkan oleh jamur rhizopus tersebut mati dan tumbuh jamur lain serta bakteri yang dapat merombak protein dalam tempe sehingga menyebabkan bau yang tidak enak. Bau busuk tersebut disebabkan oleh adanya aktivitas enzim proteolitik dalam menguraikan protein menjadi peptida atau asam amino secara anaerobik yang menghasilkan H2S, amoniak, metil sulfida, amina, dan senyawa-senyawa lainnya yang berbau busuk (Muslikhah, dkk., 2013).

Proses fermentasi juga akan mengurangi zat anti nutrisi (Onyango, dkk., 2013). Salah satu zat anti nutrisi yang terdapat dalam biji lamtoro gung yaitu mimosin. Hal ini disebabkan karena senyawa tersebut dikonsumsi oleh mikroorganisme karena strukturnya analog dengan L-tirosin. Mimosin terukur sebagai suatu asam amino, sehingga kadar protein terlarut pada biji tinggi karena di dalamnya masih terdapat senyawa mimosin (Rahayu, dkk., 2005).

\section{Kesimpulan}

Ada pengaruh waktu fermentasi terhadap kadar protein dimana semakin lama waktu fermentasi maka kadar protein semakin menurun. Kadar protein tertinggi diperoleh pada waktu fermentasi 24 jam yaitu sebesar $8.474 \%$ dan kadar protein terendah diperoleh pada waktu fermentasi 72 jam yaitu sebesar $5.733 \%$

\section{Ucapan Terima Kasih}

Penulis mengucapkan terima kasih kepada kepala laboran laboratorium Kimia FKIP UNTAD dan semua pihak yang telah membantu dalam pelaksanaan penelitian ini.

\section{Referensi}

Babu, P. D., Bhakyaraj, R. \& Vidhyalakshmi, R. (2009). A low cost nutritious food "tempeh"- A review. World Journal of Dairy \& Food Sciences, 4(1), 22-27.

Darajat, D. P., Susanto, W. H. \& Purwantiningrum, I. (2014). Pengaruh umur fermentasi tempe dan proporsi dekstrin terhadap kualitas susu tempe bubuk. Jurnal Pangan dan Agroindustri, 
2(1), 47-53.

Deliani. (2008). Pengaruh lama fermentasi terhadap kadar protein, lemak, komposisi asam lemak dan asam fitat pada pembuatan tempe. Universitas Sumatera, Medan.

Dwinaningsih, E. A. (2010). Karakteristik kimia dan sensori tempe dengan variasi bahan baku kedelailberas dan penambahan angkak serta variasi lama fermentasi., Universitas Sebelas Maret Surakarta.

Hassan, A. B., Ahmed, I. A. M., Osman, N. M., Eltayeb, M. M., Osman, G. A. \& Babiker, E. E. (2006). Effect of processing treatments followed by fermentation on protein content and digestibility of pearl millet (pennisetum typhoideum) cultivars. Pakistan Journal of Nutrition, 5(1), 86-89.

Hayati, S. (2009). Pengaruh waktu fermentasi terhadap kulaitas tempe dari biji nangka (artocarpus heterophyllus) dan penentuan kadar zat gizinya. Universitas Sumatera Utara, Medan.

Hendrayati, H. \& Askar, S. (2003). Teknik Pengenceran Analisis Protein Kasar Metode Kjeldahl Dengan Markham Still Dalam Bahan Pakan. Bogor: Badan Penelitian dan Pengembangan Pertanian.

Komari. (1999). Proses fermentasi biji lamtoro gung dengan rhizopus oryzae. Jurnal Mikrobiologi Indonesia, 4(1), 19-21.

Listyawati, S., Moeljono, M. P. E. \& Handari, S. (2001). Gambaran histologis kelenjar tiroid pada tikus (rattus norvegicus) setelah pemberian tempe lamtoro gung. Jurnal Biosmart, 3(1), 14-18.

Muctadi, D. (2010). Teknik Evaluasi Nilai Gizi Pangan. Bandung: Alfabeta.

Muslikhah, S., Anam, C. \& Andriani, M. (2013). Penyimpanan tempe dengan metode modifikasi atmosfer (modified atmosphere) untuk mempertahankan kualitas dan daya simpan. Jurnal Teknosains Pangan, 2(3), 5160.

Onyango, C. A., Ochanda, S. O., Mwasaru,
M. A., Ochieng, J. K., Mathooko, F. M. \& Kinyuru, J. N. (2013). Effects of malting and fermentation on anti-nutrient reduction and protein digestibility of red sorghum, white sorghum and pearl millet. Journal of Food Research, 2(1), 41-49.

Palupi, N., Zakaria, F. \& Prangdimurti, E. (2007). Pengaruh pengolahan terhadap nilai gizi pangan. Bogor: Departemen Ilmu \& Teknologi Pangan.

Rahayu, A., Suranto \& Purwoko, T. (2005). Analisis karbohidrat, protein, dan lemak pada pembuatan kecap lamtoro gung (leucaena leucocephala) terfermentasi aspergillus oryzae. Jurnal Biotekhnologi, 2(1), 14-20.

Rosida, D. F., Sudaryati, H. P. \& Costantia, F. (2009). Kajian peran angkak pada kualitas tempe kedelai-lamtoro gung (leucaena leucocephala). Universitas Pembangunan Nasional, Jawa Timur.

Sadli. (2014). Analisis kandungan karbohidrat lemak dan protein dari biji durian (durio zibenthinus murr) dengan variasi waktu fermentasi. Universitas Tadulako, Palu.

Sayudi, S., Herawati, N. \& Ali, A. (2015). Potensi biji lamtoro gung dan biji kedelai sebagai bahan baku pembuatan tempe komplementasi. Jurnal Online Mahasiswa (JOM) Universitas Riau, 2(1), 1-9.

Setyaningsih, E., Purwani, E. \& Sarbini. (2009). Perbedaan kadar kalsium, albumin dan daya terima pada selai cakar ayam dan kulit pisang dengan variasi perbandingan kulit pisang yang berbeda. Jurnal Ilmu Kesehatan, I(2), 27-37.

Silvia, I. (2009). Pengaruh penambahan variasi berat inokulum terhadap kualitas tempe biji durian (durio zibenthinus). Universitas Sumatera Utara, Medan

Widodo, T. (2012). Pemanfaatan biji nangka (artocarpus heterophyllus lam) sebagai substrat pembuatan tempe biji nangka dengan variasi kadar ragi dan lama fermentasi. Universitas Islam Negeri Sunan Kalijaga, Yogyakarta. 